\title{
HABITAT INTERACTION BETWEEN TWO SPECIES OF CHIPMUNK IN THE BASIN AND RANGE PROVINCE OF NEVADA
}

\author{
Christopher Lowrey ${ }^{1,2}$ and Kathleen Longshore ${ }^{1}$
}

\begin{abstract}
AвstRACT.-Interspecies interactions can affect how species are distributed, put constraints on habitat expansion, and reduce the fundamental niche of the affected species. Using logistic regression, we analyzed and compared 174 Tamias palmeri and 94 Tamias panamintinus within an isolated mountain range of the Basin and Range Province of southern Nevada. Tamias panamintinus was more likely to use pinyon/ponderosa/fir mixed forests than pinyon alone, compared to random sites. In the presence of T. palmeri, however, interaction analyses indicated T. panamintinus was less likely to occupy the mixed forests and more likely near large rocks on southern aspects. This species-by-habitat interaction data suggest that T. palmeri excludes T. panamintinus from areas of potentially suitable habitat. Climate change may adversely affect species of restricted distribution. Habitat isolation and species interactions in this region may thus increase survival risks as climate temperatures rise.
\end{abstract}

RESUMEN.-Las interacciones entre las especies pueden afectar la manera en que se distribuyen, imponer restricciones a la expansión del hábitat y reducir el nicho fundamental de las especies afectadas. Por medio de regresión logística, analizamos y comparamos 174 Tamias palmeri y 94 Tamias panamintinus dentro de una cadena aislada de montañas de la región Basin and Range del sur de Nevada. Se encontró a T. panamintinus con más frecuencia en los bosques mixtos de pinos piñoneros, ponderosa y abetos que en los bosques conformados únicamente de pinos piñoneros, al comparar con lugares al azar. Sin embargo, los análisis de interacción indicaron que, en presencia de T. palmeri, hubo menos probabilidad de que T. panamintinus se encontrara en los bosques mixtos y más probabilidad de que se encontrara cerca de las rocas grandes en la parte sur. Esta interacción entre especies y hábitat sugiere que Tamias palmeri excluye a T. panamintinus de áreas donde el hábitat podría ser apropiado. El cambio climático puede afectar de manera desfavorable a especies con distribución restringida. Por lo tanto, el aislamiento del hábitat y la interacción entre las especies en esta región pueden incrementar los riesgos de supervivencia al aumentar las temperaturas ambientales.

When 2 or more similar species exhibit habitat overlap, important ecological questions arise about the way these species successfully occupy the same place concurrently (Brown 1971), the role of habitat structure and composition in the maintenance of species separation (Sharples 1983), and the potential interactions between these species (Schoener 1974, Trombulak 1985). Overlap zones are sometimes found at habitat edges where vegetation structure and composition are transitioning (Sheppard 1970). In mountainous regions, where an elevation gradient additionally affects temperature and precipitation, these overlap zones may be especially affected by climate change (Inouye et al. 1999). Determining specific environmental correlates of separation is an important step in understanding potential reasons for the maintenance of species separation (Sharples 1983) and is essential for predicting the potential effects of climate change (Ditto and Frey 2007). Determination of these correlates requires measuring habitat use of sympatric species both independently and simultaneously. A change in habitat use of one or more species due to the presence of the other can be a strong indicator of species interaction (Chappell 1978). The genus Tamias has 22 species in North America, 21 of which occur in the West. The genus generally occurs in forested regions from valley floors to above timberline. Several Tamias species overlap in their distribution, and the attributed causes for why they remain separated are varied (Brown 1971, Chappell 1978, Sharples 1983, Perault et al. 1997). Sympatric Tamias express a range of tolerance from mutual exclusion (Chappell 1978) to broad overlap (Sharples 1983). Brown (1971) found that separation between $T$. dorsalis and $T$. umbrinus in the central Great Basin was explained by competitive exclusion. Tamias amoenus similarly excludes T. minimus in Alberta (Sheppard 1970). Tamias speciosus and T. amoenus in the

\footnotetext{
${ }^{1}$ U.S. Geological Survey, Western Ecological Research Center, Las Vegas Field Station, 160 North Stephanie Street, Henderson, NV 89074.

${ }^{2}$ E-mail: clowrey@usgs.gov
} 
northern Sierra Nevada Mountains (Sharples 1983), and T. minimus and T. umbrinus in the Uinta Mountains of northeastern Utah (Perault et al. 1997), maintain sympatric overlap by using different vegetation types.

Much research on Tamias species separation has naturally occurred within the northwestern United States, likely because this is where many Tamias species occur. However, an excellent opportunity exists for expanding our understanding of species separation within the southern Basin and Range Province of North America. This landscape provides advantages to researchers addressing species interactions and the potential effects of climate change on species borders. It is an area of high mountain islands separated by low deserts that have isolated many species for thousands of years (Rickart 2001); the steep elevation gradient provides clear demarcation of habitat types; and the endemic species contribute significantly to the biodiversity of the surrounding region (Allen et al. 1991, Lomolino 2001, Rickart 2001, McCain 2007). Global and regional environmental change threatens species of restricted distributions (McDonald and Brown 1992, Rosenzweig and Clark 1994), and these small, isolated populations are more susceptible to extinction due to their inability to replenish populations by immigration. The effects of environmental change on isolated populations is of particular importance in arid regions of southwestern North America, where a transition to more arid climatic conditions has been documented, resulting in less precipitation (Seager et al. 2007) and shifts in the timing of precipitation (Weltzin et al. 2003).

Tamias palmeri and Tamias panamintinus are isolated species with overlapping distributions on the Spring Mountains of southern Nevada. Tamias palmeri occurs from approximately $2200 \mathrm{~m}$ to above $3000 \mathrm{~m}$ in elevation (Best 1993), while T. panamintinus occurs below $2500 \mathrm{~m}$ to approximately $1230 \mathrm{~m}$ (Best et al. 1994). Tamias palmeri occurrence is associated with the lower slopes of fir (Abies concolor) forest and proximity to water, and in this species, population size and survival increases with increasing density of shrub species (Ribes cereum) (Lowrey and Longshore in review). Tamias panamintinus has been associated with singleleaf pinyon (Pinus monophylla) and juniper (Juniperus osteosperma) forests (Best et al. 1994). Tamias panamintinus has been found at elevations up to $3000 \mathrm{~m}$ (Best et al. 1994); however, it is not found at these elevations in the Spring Mountains (Deacon et al. 1964).

In this study, we compare and contrast the habitat associations of T. palmeri and T. panamintinus and estimate the actual distribution of these 2 species from genetically verified location data. We then model the potential distribution based on habitat use and compare the actual to the potential distributions. Finally, we analyze the environmental variables within the overlap zone to determine species interaction in terms of habitat use.

\section{Methods}

Study Area

The Spring Mountains are located in the Basin and Range Province of the eastern Mojave Desert, approximately $40 \mathrm{~km}$ northwest of Las Vegas, Nevada. The range, consisting largely of sedimentary limestone (Longwell 1951), contains over 10 peaks above $3300 \mathrm{~m}$, the highest at $3632 \mathrm{~m}$. Vegetation above $2500 \mathrm{~m}$ consists of conifer/mixed conifer forest associations: ponderosa (Pinus ponderosa), white fir (Abies concolor), and bristlecone pine (Pinus longaeva). Areas below $2500 \mathrm{~m}$ and above the desert region are dominated by single-leaf pinyon pine and curl-leaf mountain mahogany (Sada and Nachlinger 1996). Tamias habitat is isolated from similar habitat in neighboring mountain ranges by the surrounding desert floor that is just above $700 \mathrm{~m}$. Annual precipitation is typically $<13 \mathrm{~cm}$ in the lower areas and as high as $71 \mathrm{~cm}$ at higher elevations. The upper slopes are further subject to extreme seasonality, with snow cover 5-7 months of the year. Mean yearly average temperature is $10{ }^{\circ} \mathrm{C}$ at $2000 \mathrm{~m}$ (Sada and Nachlinger 1996).

\section{Animal Location Data, Identification,} and Actual Distribution

We used animal locations from thirty-four 2-km trapping transects to estimate the actual distribution of T. panamintinus. We trapped 12 transects within the pinyon pine/juniper habitat association at the lowest elevations, 12 across the ponderosa-pinyon pine transition zone, and 10 within the ponderosa pine association to systematically sample the range from June through August of 2008 and 2009. Transects were $2 \mathrm{~km}$ long and placed not less 
TABle 1. Habitat variables measured for a Panamint and Palmer's chipmunk interaction study in the Spring Mountains, Nevada, 2008-2009.

\begin{tabular}{|c|c|c|c|}
\hline Habitat variable & Mean & $\mathrm{SD}$ & Range \\
\hline$\%$ cover pinyon-juniper & 25.7 & 28.2 & $0-95$ \\
\hline$\%$ cover mahogany & 12.6 & 9.2 & $0-95$ \\
\hline$\%$ cover ponderosa & 8.3 & 12.4 & $0-95$ \\
\hline$\%$ cover fir & 3.5 & 13.0 & $0-85$ \\
\hline$\%$ cover sagebrush & 17.4 & 23.0 & $0-100$ \\
\hline$\%$ cover Ribes shrub & 2.7 & 6.4 & $0-45$ \\
\hline$\%$ cover forest litter & 37.4 & 32.3 & $0-80$ \\
\hline Pinyon-juniper density/plot & 1.8 & 2.8 & $0-13$ \\
\hline Mahogany density/plot & 2.1 & 3.7 & $0-20$ \\
\hline Ponderosa pine density/plot & 1.4 & 3.0 & $0-33$ \\
\hline Fir density/plot & 3.4 & 5.9 & $0-39$ \\
\hline Sagebrush density/plot & 6.4 & 9.3 & $0-58$ \\
\hline Ribes shrub density/plot & 1.3 & 2.8 & $0-17$ \\
\hline Distance to water (m) & 2158.2 & 1797.7 & $80-8026$ \\
\hline Occurrence of water source & 0.02 & 0.1 & $0-1$ \\
\hline Density of downed log/plot & 0.5 & 1.2 & $0-15$ \\
\hline Density of large rocks a/plot & 0.5 & 1.2 & $0-10$ \\
\hline$\%$ slope & 35.5 & 16.4 & $0-122$ \\
\hline Hillshade $^{b}$ & 141.9 & 104.7 & $0-254$ \\
\hline
\end{tabular}

Large rocks $=1 \mathrm{~m} \times 1 \mathrm{~m}$.

b Measure of sun radiation intensity as a function of surface angle. Azimuth from 12pm 7/2009.

than $2 \mathrm{~km}$ or more than $5 \mathrm{~km}$ apart. Within each transect, one $25 \times 9 \times 8$-cm folding aluminum trap (H.B. Sherman Trap Co., Tallahassee, FL) was set every $40 \mathrm{~m}$ along a single line for 4 days (50 traps per transect). Different chipmunk species are generally difficult to distinguish, and T. palmeri and T. panamintinus are especially similar in appearance (Best 1993). Therefore, we used genetic (mitochondrial amplification) analyses on tissue samples to identify species (B. Riddle and S. Mantooth, University of Nevada, Las Vegas, genetics lab). We maintained a buffer of $300 \mathrm{~m}$ above the highest elevational extent of locations successfully capturing $T$. panamintinus to estimate the distribution area across the Spring Mountains. To establish the actual distribution of T. palmeri, we used the results from Lowrey and Longshore (in review), who used similar methods.

\section{Vegetation and Topographic Data Collection}

Vegetation species composition, structure, and topographical variables were measured within $8 \mathrm{~m}$ radius plots centered on each trap that successfully captured a chipmunk (Table 1). Habitat variables were also measured at 350 plots randomly placed throughout the study area. Percentage of tree, shrub, and forest litter cover were estimated by standing at 20 systematically placed points within each plot and looking straight up (canopy) and down (shrub, litter) through a $20 \mathrm{~cm}$ long by $3 \mathrm{~cm}$ diameter tube. Percentage cover was derived by counting the number of times the canopy (or shrubs) covered the line of sight (hits) and dividing that number by 20 (total; modified from Dueser and Shugart 1978). Densities of trees, shrubs, snags, downed logs $(>0.5 \mathrm{~m}$ in diameter and $>2 \mathrm{~m}$ in length), and large rocks $(\geq 1 \mathrm{~m} \times 1 \mathrm{~m})$ were measured by census within each plot. Tree heights were measured with a hypsometer. Water source locations, either wet ground or open water, were also documented. Percentage slope, aspect (2 categorical variables of north $[=1]$ or south $[=0]$ facing), and distance to water were measured in a GIS application (ArcMap 9.3, Environmental Systems Resource Institute, Redlands, CA). Hillshade, a geometric measure of how much radiation the surface is exposed to as a function of surface angle (range 0-255, $255=$ maximum radiation), was measured in a GIS application. As a measure of general forest type, we used the P. monophylla, A. concolor, and $P$. ponderosa mixed forest vegetation classifications of the Southwest Regional Gap Analyses Project (ReGap; 2007) as categorical variables (either species present $=1$, not present $=0)$.

\section{Habitat Availability and Interaction}

We used logistic regression analyses with 94 successful T. panamintinus and 150 random 


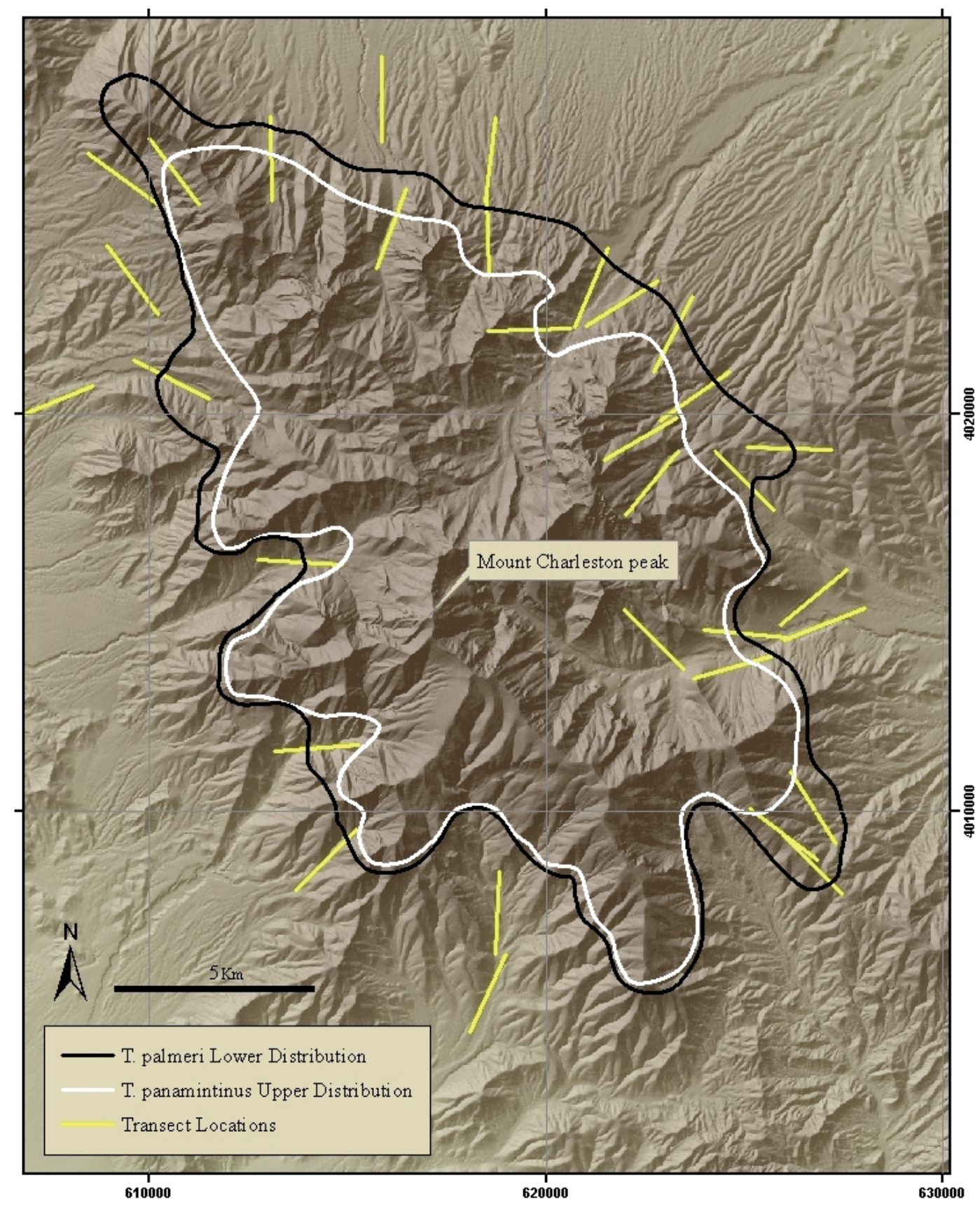

Fig. 1. Actual distribution extents of Tamias palmeri and T. panamintinus estimated from genetically verified location data. Spring Mountains, Nevada, 2009.

points to create the T. panamintinus resource selection function (RSF) model of habitat availability (Menard 1995, Manly et al. 2002, Johnson et al. 2006; SPSS statistical software, Somers, NY). These RSF values are proportional to the relative probability of animal occurrence across the available habitat (Boyce and McDonald 1999, Johnson et al. 2006). We then used the RSF model as developed by Lowrey and Longshore (in review; 
TABLE 2. Habitat variables contributing to Tamias panamintinus occurrence in the Spring Mountains, Nevada.

\begin{tabular}{lcccrr}
\hline Habitat variable & $\beta$ & SE & Wald & df & $P$ \\
\hline Hillshade $^{\mathrm{a}}$ & 0.0262 & 0.004 & 42.37 & 1 & $<0.000$ \\
Pinyon pine forest $^{\mathrm{b}}$ & 1.968 & 0.563 & 4.517 & 1 & 0.033 \\
Pinyon/ponderosa mixed forest $^{\mathrm{b}}$ & 2.856 & 0.884 & 10.44 & 1 & 0.001 \\
\hline
\end{tabular}

a Measure of sun radiation intensity as a function of surface angle. Azimuth from 12pm 7/2009.

bCategorical variable: 1 = pinyon, 2 = pinyon/ponderosa. Values relative to the pinyon forest type (reference category).

$\mathrm{RSF}=[-0.0365 *$ percent slope $]+[-0.0018 *$ distance to water sources $]+[0.1562 *$ aspect $]$ $+[0.7164 *$ bristlecone/fir mixed forest $]+$ $[-1.326 *$ ponderosa/pinyon pine mixed forest]) to determine T. palmeri habitat availability. Aspect and forest variables were categorical. Model chi-square tests and Wald statistics were used to assess overall model fit and the strength of individual variable contributions. Model strength and accuracy was evaluated using the area under the curve (AUC) of a receiver operating characteristic (ROC) analyses. We used the Hawth's Tools ${ }^{\circledR}$ extension within ArcMap to generate the random points across the study area and spatially enforced a minimum distance of $10 \mathrm{~m}$ between points. We confirmed our logistic regression results by using a general linear model (GLM) to determine habitat use differences between the 2 species within the overlap zone.

To analyze interaction between the 2 species, we first constrained our used and available data to the areas above the lower distribution line of T. palmeri (within the actual overlap zone). We used a single logistic regression model to compare habitat use for both species. Where the response variable was use versus available, species was a covariate factor in the model, and all interaction terms between species and covariates were present (Manly et al. 2002). Random points were generated independently for each species.

\section{Results}

Transects captured 293 individual chipmunks, of which 268 were genetically identified (174 T. palmeri and 94 T. panamintinus). All T. panamintinus were captured below 2660 $\mathrm{m}$, including 8 above $2400 \mathrm{~m}(\bar{x}=2328$, SD $=$ 188.8), and all T. palmeri were found above $2085 \mathrm{~m}(\bar{x}=2593$, SD $=318)$. Chipmunks were captured on 28 of the 34 transects, which allowed us to estimate the actual distribution of $T$. panamintinus and compare it directly to Lowrey and Longshores' (in review) T. palmeri distribution (Fig. 1). We found that T. panamintinus occurrence, compared against all available habitat, was predicted by pinyon pine, by increasing hillshade values (increasing exposure to radiation), and by the occurrence of ponderosa/pinyon pine mixed forest of the Spring Mountains (overall model: $\chi^{2}=163.42$, $\mathrm{R}^{2}=0.66$; Table 2). Area under the curve (AUC) of 0.910 from ROC analysis indicated a strong ability of the model to discriminate T. panamintinus points from random points. Tamias palmeri occurrence was predicted by slope, aspect, distance to water, fir trees, and increasing shrub (Ribes spp.) cover (Lowrey and Longshore in review). Our RSF models indicated habitat suitability for T. panamintinus extended significantly above the distribution estimated by location data (Fig. 2). Our GLM analyses of habitat use between these 2 species confirmed the greater use of fir trees by T. palmeri (Deacon et al. 1964, Best 1993) and the greater use of pinyon pine and large rocks by $T$. panamintinus (Best et al. 1994; overall model: $F_{4,187}=73.33, P \leq 0.001$; Table 3). Using data occurring only within the overlap zone (144 T. palmeri and 64 T. panamintinus), interaction terms indicated that, relative to T. palmeri, T. panamintinus was more likely to be near large rocks and southerly facing aspects and less likely to be near fir trees within the pinyon/ponderosa mixed forest (Table 4).

\section{DisCUSSION}

Although we found significant potential for habitat overlap (Fig. 2), location data indicated that Tamias palmeri and T. panamintinus remain generally well separated within the Spring Mountains. Compared to random points not constrained to the overlap zone, $T$. panamintinus demonstrated a preference for pinyon/ponderosa mixed forest habitats at the upper elevation range of the pinyon forests (Best et al. 1994). However, when we constrained the analyses to the species overlap 


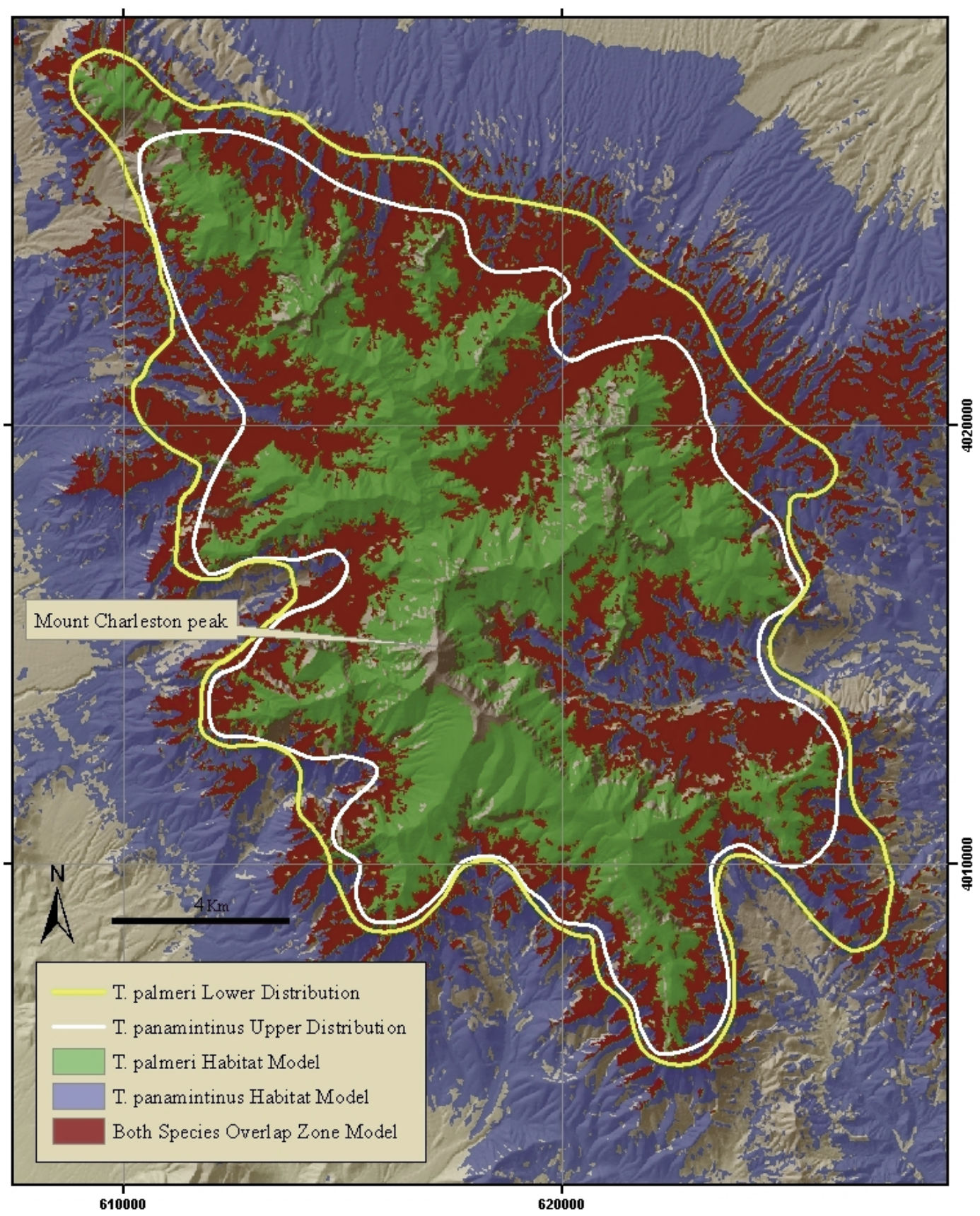

Fig. 2. Actual distribution extent of both species of chipmunk and habitat models indicating potential distributions for Tamias panamintinus and T. palmeri and their overlap zone within the Spring Mountains, Nevada, 2009.

zone within presence of T. palmeri in the interaction analyses, no such preference was found, and T. panamintinus was more likely found outside these mixed ponderosa areas in exclusively pinyon pine habitat associations. This suggests potential exclusion of T. panamintinus from areas with ponderosa and fir trees, a likely food source for both chipmunk species (Best et al. 1994).

Tamias panamintinus occurs in areas of relatively high solar exposure and, as a result, is 
TABLE 3. General linear model results showing significantly different habitat use variables within the overlap zone of Tamias palmeri and Tamias panamintinus. Spring Mountains, Nevada, 2009.

\begin{tabular}{|c|c|c|c|c|}
\hline Habitat variable & $F$ & $P$ & Mean difference & $\mathrm{SE}$ \\
\hline$\%$ fir tree cover & 13.51 & $<0.001$ & $9.3^{\mathrm{a}}$ & 2.5 \\
\hline Pinyon-juniper density & 9.05 & 0.003 & $1.3^{\mathrm{b}}$ & 0.4 \\
\hline$\%$ sagebrush shrub cover & 17.94 & $<0.001$ & $15.1^{\mathrm{b}}$ & 3.4 \\
\hline Large $\operatorname{rock}(\geq 1 \mathrm{~m} \times 1 \mathrm{~m})$ density & 13.64 & $<0.001$ & $0.7^{\mathrm{b}}$ & 0.2 \\
\hline
\end{tabular}

aT. palmeri $>$ T. panamintinus.

${ }^{\mathrm{b}}$ T. panamintinus $>$ T. palmeri.

TABLE 4. Significant interactions between Tamias palmeri (reference category) and Tamias panamintinus within the Spring Mountains of southern Nevada, 2009.

\begin{tabular}{lccccc}
\hline Habitat variable interactions & $\beta$ & SE & Wald & df & $P$ \\
\hline Species $^{\mathrm{a}} \times$ fir tree density & -0.0975 & 0.0740 & 4.90 & 1 & 0.027 \\
Species $^{\mathrm{a}} \times$ large rock density & 0.5095 & 0.2005 & 6.46 & 1 & 0.011 \\
Species $^{\mathrm{a}} \times$ aspect $^{\mathrm{c}}$ & 2.152 & 0.4828 & 19.86 & 1 & $<0.0001$ \\
\hline
\end{tabular}

aReference category $=T$. palmeri.

${ }^{b}$ Large rocks $\geq 1 \mathrm{~m} \times 1 \mathrm{~m}$.

${ }^{\mathrm{c} C a t e g o r i c a l:} 0=$ southerly facing slopes, $1=$ northerly facing slopes (reference category).

able to exploit the pinyon forest on the lower elevation and southerly exposed areas. In contrast, T. palmeri is known to have a narrow thermoneutral zone (Best 1993) and is likely physiologically unable to exploit areas of higher temperatures. Tamias panamintinus has been found in areas above $3100 \mathrm{~m}$ (Best et al. 1994), suggesting a potentially broad overlap of the fundamental niche of these species. However, intensive trapping shows T. panamintinus is not found above $2600 \mathrm{~m}$ in the Spring Mountains (Deacon et al. 1964, Lowrey and Longshore in review), and this elevational limit represents an unexplained constraint on the species distribution. Based on changes in habitat use of T. panamintinus in the presence of $T$. palmeri, the known physiological constraints of T. palmeri, and the lack of occurrence of $T$. panamintinus at higher elevations, we speculate that T. panamintinus is excluded from areas within the thermoneutral zone of T. palmeri by habitat preference. This may represent a distributional limit for T. panamintinus, established through habitat selection as a mechanism by which the species avoids energetically costly encounters with the larger T. palmeri (States 1976, Sharples 1983). If T. panamintinus was primarily excluded by behavioral interaction, we would expect $T$. panamintinus to be found at higher elevations (Chappell 1978). However, whether behavior represents an additional mechanism of separation remains to be systematically investigated.
The isolation of conifer forests on the Spring Mountains makes the nonflying species there particularly susceptible to changes in climate (Rickart 2001, Ditto and Frey 2007). If T. panamintinus, already isolated at the lower elevations by desert and constrained at the higher elevations by habitat preference and interspecies interaction, is further subjected to increasing temperatures and dryer conditions of climate change, the probability of extinction for this species may increase (Ditto and Frey 2007).

\section{ACKNOWLEDGMENTS}

We express our sincere thanks for both funding and support for this project provided by the Clark County Desert Conservation Program, the U.S. Forest Service, the U.S. Fish and Wildlife Service, and the University of Nevada, Las Vegas. We also sincerely thank Dr. Julie Yee for statistical advice. We are particularly grateful to Diego Johnson, Lee Rindlisberger, Sara Schuster, Rebecca Rookey, John McLaughlin, Adam Anderson, Stephanie Busby, Chris Bertrand, Leah Kerschner, Christina Golden, Sara Blocker, Phil Wasz, Wade Boan, Kim Horton, and Chiaki Lowrey for their untiring collection of data under often very difficult field conditions. The use of trade, product, or firm names in this publication is for descriptive purposes only and does not imply endorsement by the U.S. Government. 


\section{Literature Cited}

Allen, R.B., R.K. Peet, and W.L. BaKer. 1991. Gradient analysis of latitudinal elevation in southern Rocky Mountain forests. Journal of Biogeography 18:123-139.

Best, T.L. 1993. Tamias palmeri. Mammalian Species 443:1-6.

Best, T.L., R.G. Clausen, and J.A. Clawson. 1994. Tamias panamintinus. Mammalian Species 468:1-6.

Boyce, M.S., AND L.L. MCDonald. 1999. Relating populations to habitats using resource selection functions. Trends in Ecology and Evolution 14:268-272.

Brown, J.H. 1971. Mechanisms of competitive exclusion between two species of chipmunks. Ecology 52 305-311.

Chappell, M.A. 1978. Behavioral factors in the altitudinal zonation of chipmunks (Eutamias). Ecology 59: 565-579.

Deacon, J.E., W.G. Bradley, and K.M. Larsen. 1964. Ecological distribution of the mammals of Clark Canyon, Charleston Mountains, Nevada. Journal of Mammalogy 45:397-409.

DitTo, A.M., AND J.F. Frey. 2007. Effects of ecogeographic variables on genetic variation in montane mammals: implications for conservation in a global warming scenario. Journal of Biogeography 34: $1136-1149$.

Dueser, R.D., AND H.H. Shugart. 1978. Microhabitats in forest floor small mammal fauna. Ecology 59:89-98.

Inouye, D.W., B. BarR, K.B. ARmitage, AND B.D. InOuYe. 1999. Climate change is affecting altitudinal migrants and hibernating species. Proceedings of the National Academy of Sciences 94:1630-1633.

Johnson, C.J., S.E. Nielson, E.H. Merrill, T.L. MCDonalD, AND M.S. BoycE. 2006. Resource selection functions based on use availability data: theoretical motivation and evaluation methods. Journal of Wildlife Management 70:347-357.

LOMOLINO, M.V. 2001. Elevation gradients of species density: historical and prospective views. Global Ecology and Biogeography 10:3-13.

LONGWELL, C.R. 1951. Geology of the Charleston Mountain area. In: I.W. Clokey, editor, Flora of the Charleston Mountains, Clark County, Nevada. University of California Press, Berkeley, CA.

Lowrey, C.E. 2002. Ecology and growth of Tamias palmeri and testing of a protocol to monitor habitat relationships. Master's thesis, University of Nevada, Las Vegas, NV. 73 pp.

Lowrey, C.E., AND K.M. Longshore. In review. Ecology, distribution and predictive modeling of Tamias palmeri: a high elevation small mammal.

Manly, B.F.J., L.L. McDonald, D.L. Thomas, T.L. MCDONALD, AND W.P. ERICKSON. 2002. Resource selection by animals: statistical analyses and design for field studies. 2nd edition. Kluwer, Boston, MA.
McCain, C.M. 2007. Area and mammalian elevational diversity. Ecology 88:76-86.

McDonald, K.A., AND J.H. Brown. 1992. Using montane mammals to model extinctions due to global change. Conservation Biology 6:409-415.

Menard, S. 1995. Applied logistic regression analyses. Quantitative Applications in the Social Sciences No. 07-106. Sage University, Thousand Oaks, CA.

Perault, D.R., P.G. Wolf, and T.C. Edwards Jr. 1997. Hierarchical analyses of genetic partitioning by Tamias minimus and T. umbrinus. Journal of Mammalogy 78:134-145.

RicKART, E.A. 2001. Elevational diversity gradients, biogeography and the structure of montane mammal communities in the Intermountain Region of North America. Global Ecology and Biogeography 10: $77-100$.

RosenzWeig, M.I., AND C.W. CLARK. 1994. Island extinction rates from regular census. Conservation Biology 8:491-494.

Sada, D.W., AND J.L. NaChlinger. 1996. Spring Mountains ecosystem: vulnerability of spring-fed aquatic and riparian systems to biodiversity loss. Report to U.S. Fish and Wildlife Service, Nevada State Office. $40 \mathrm{pp}$.

Schoener, T.W. 1974. Resource partitioning in ecological communities. Science 185:27-38.

Seager, R., M. Ting, I. Held, Y. Kushnir, J. Lu, G. Vecchi, H. Huang, N. Harnik, A. Leetmaa, N. Lau, C. Li, J. VELEZ, AND N. NAIK. 2007. Model projections of an imminent transition to a more arid climate in southwestern North America. Science 316:1181-1184

Sharples, F.E. 1983. Habitat use by sympatric species of Eutamias. Journal of Mammalogy 64:572-579.

Sheppard, D.H. 1970. Competition between two chipmunk species (Eutamias). Ecology 52:320-329.

StATES, J.B. 1976. Local adaptations in chipmunk (Eutamias amoenus) populations and evolutionary potential at species borders. Ecological Monographs 46:221-256.

Trombulak, S.C. 1985. The influence of interspecific competition on home range size in chipmunks (Eutamias). Journal of Mammalogy 66:329-337.

Weltzin, J.F., M.E. Loik, S. Schwinning, D.G. Williams, P.A. Fay, B.M. Haddad, J. Harte, T.E. Huxman, A.K. Knapp, G. Lin, et aL. 2003. Assessing the response of terrestrial ecosystems to potential changes in precipitation. BioScience 53:941-952.

Received 21 October 2011 Accepted 22 January 2013 